\title{
Design and Synthesis of Some 3-Substituted-2-[(2,4-dichlorophenoxy)- methyl]quinazolin-4(3H)-one Derivatives as Potential Anticonvulsant Agents
}

\author{
Safinaz El-Sayed Abbas, ${ }^{a}$ Fadi Mohsen Awadallah, ${ }^{* a}$ Nashwa Ahmed Ibrahim, ${ }^{b, c}$ \\ Eman Gaber Said, ${ }^{c}$ and Gihan $\mathrm{Kamel}^{d}$ \\ ${ }^{a}$ Pharmaceutical Chemistry Department, Faculty of Pharmacy, Cairo University; Kasr El-Eini, Cairo 11562, Egypt: \\ ${ }^{b}$ Medicinal Chemistry Department, Faculty of Pharmacy, Umm-Al-Qura University; Makkha 13174, Kingdom of \\ Saudi Arabia: ${ }^{c}$ Pharmaceutical Chemistry Department, Faculty of Pharmacy, Beni-Suef University; Beni-Suef 62111, \\ Egypt: and ${ }^{d}$ Pharmacology Department, Faculty of Veterinary Medicine, Cairo University; Giza 12613, Egypt. \\ Received December 13, 2012; accepted May 2, 2013
}

Series of 2,3-disubstituted quinazolinone derivatives and a $[1,2,4]$ triazino[2,3-c]quinazolinone featuring the pharmacophoric elements of anticonvulsant drugs were designed and synthesized. Target compounds were screened for their anticonvulsant activity using the subcutaneous pentylenetetrazole (s.c. PTZ) and maximal electroshock (MES) models. The s.c. PTZ test showed that the most active compound was the amide derivative 9c having a protective dose $50\left(\mathrm{PD}_{50}\right)$ of $200.53 \mu \mathrm{mol} / \mathrm{kg}\left(\mathrm{PD}_{50}\right.$ of phenobarbitone $\left.=62.18 \mu \mathrm{mol} / \mathrm{kg}\right)$; nevertheless, this low potency is outweighed by the much higher safety profile of $9 \mathrm{c}\left(\mathrm{LD}_{50}>3000 \mathrm{mg} / \mathrm{kg}\right)$. In the MES screening, seven compounds were equal to or more active than phenytoin; some of these compounds were less neurotoxic than phenytoin. Few compounds such as $9 \mathrm{c}$ and 10 were effective in both models. $\mathrm{LD}_{50}$ for the most active compounds was calculated.

Key words quinazolinone; pentylenetetrazole model; maximal electroshock model; anticonvulsant activity; $\mathrm{LD}_{50}$; neurotoxicity

Epilepsy is an all-pervading neurological disorder characterized by recurrent seizures and affecting about $1 \%$ of the world's population. In the last few decades, many efforts devoted for the development of novel therapeutics resulted in the availability of several newer agents as promising anticonvulsants. ${ }^{1,2)}$ The efficacy of many of the marketed antiepileptic drugs is greatly compromised by severe side effects such as ataxia, drowsiness, gingival hyperplasia, gastrointestinal disturbances, and megaloblastic anaemia. Moreover, about $30 \%$ of patients have uncontrolled seizures. ${ }^{3-8)}$ Therefore, continued search for safer and more effective anticonvulsants is urgently necessary.

The insufficient information on the cellular mechanism of epilepsy in human and the complex mechanism of action of most of the antiepileptic drugs makes it difficult to use rational methodologies in the discovery of new antiepileptic drugs. Therefore, another design approach based on the existence of different pharmacophores that were established through the analysis of structural characteristics of clinically effective drugs as well as other antiepileptic compounds was adopted. ${ }^{9-11)}$ In the literatures, it is well documented that one of the important core fragments is defined by the presence of: i) hydrogen donor/acceptor unit (HAD), ii) one electron donor atom (D), and iii) a hydrophobic domain (A) (aryl ring substituted/unsubstituted). ${ }^{12-15)}$ These structural features were found in the first generation drugs including the well-established antiepileptics such as carbamazepine or phenytoin, and the newest drugs e.g., Felbamate; and in the second generation antiepileptic drugs and the drugs in clinical trial (Fig. 1). Efforts devoted in the recent years based on this pharmacophore model resulted in the availability of several newer drugs (such as retigabine, tiagabine, lamotrigine, pregabalin, stiripentol,

The authors declare no conflict of interest. zonisamide, topiramate, levetiracetam) as promising antiepileptics. ${ }^{1)}$

Literature survey revealed that quinazoline is a privileged lead molecule for scheming potential bioactive agents that exhibits a broad spectrum of bioactivity such as anti-tumor, $\left.{ }^{16}\right)$ anti-inflammatory ${ }^{17)}$ and antimicrobial activities. ${ }^{18,19)}$ This is in addition to the anticonvulsant activity of many quinazolinone derivatives, illustrated in Fig. 2, such as methaquolone I which was an important landmark in the field of synthetic anticonvulsant, and whose quinazoline core was responsible for its activity. ${ }^{20)}$ Other related 3-substituted derivatives such as II and III showed good protection against maximal electroshock and subcutaneous Metrazol-induced seizures. ${ }^{21,22)}$ Further investigations on methaquolone led to the development of the 8-hydrazinocarboxylate derivative IV which exhibited high anticonvulsant profile in pentylenetetrazole (PTZ) and maximal electroshock model (MES) assays. ${ }^{23)}$ Recently, the 2-methylsulfonamido-quinazolinedione derivative $\mathbf{V}$ was identified with a low $\mathrm{ED}_{50}$ in animal model of anticonvulsant activity after oral dosage ${ }^{24)}$ (Fig. 2). Moreover, many citations pertaining to the anticonvulsant activity of quinazolines were reviewed in literature supporting the importance of this nucleus as core for anticonvulsant agents. ${ }^{25-28)}$

Interested in the anticonvulsant activity of quinazolinones, the first author previously reported the synthesis and potent anticonvulsant activity of some 3-N-substituted-2-substitutedphenoxypropylquinazolinone derivatives $\mathbf{V I}^{29,30}$ (Fig. 2). In continuation of these latter investigations, this research aimed to optimize previously obtained molecular hits through contraction of the side chain in position 2 of the quinazolinone nucleus and introducing two chloro functions on the phenyl ring to have a 2,4-dichlorophenoxymethyl group. In addition, the substitution in position 3 was extended through an acetamido spacer to which a diversity of groups serving as hydro- 


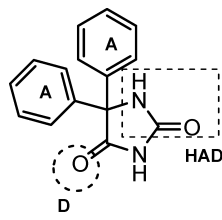

Phenytoin

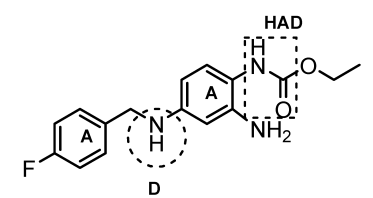

Retigabine

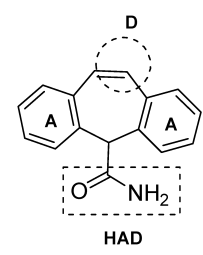

Carbamazepine<smiles>NC(=O)OCC(COc1ccco1)c1ccccc1</smiles>

Felbamate

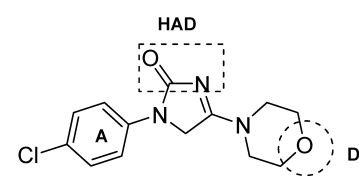

AWD 131
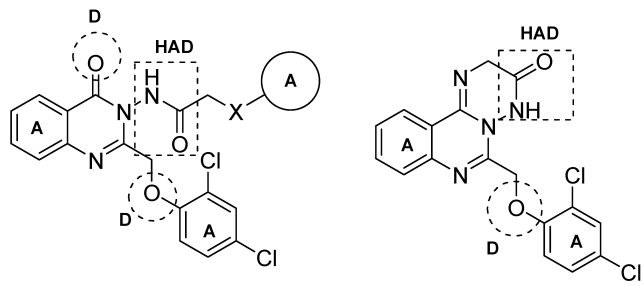

Model of target compounds

Fig. 1. Pharmacophoric Pattern of Well Known Antiepileptics and Model Target Compounds with Its Vital Structural Features (A) Hydrophobic aryl ring system (HAD), hydrogen bond acceptor/donor domain (D), electron donor moiety.<smiles>Cc1ccccc1-n1c(C)nc2ccccc2c1=O</smiles>

Methaquolone I<smiles></smiles>

II $\mathrm{R}=\mathrm{CH}_{3}$ III $\mathrm{R}=\mathrm{Cl}$<smiles>CCOC(=O)NC(=O)COc1cccc2c(=O)n(-c3ccccc3C)n(C)c12</smiles>

IV

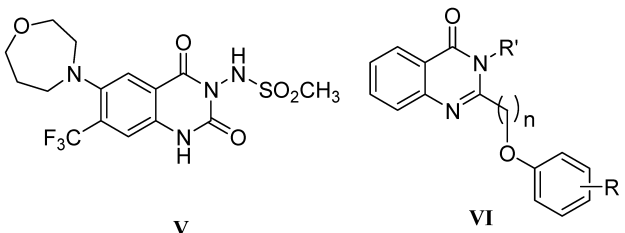

Fig. 2. Examples of Some Quinazolinone-Based Anticonvulsant Agents

phobic domains were attached. Therefore, four series of target compounds were prepared; the benzylidine amino derivatives $\mathbf{5 a}-\mathbf{e}$, their benzylamino congeners $\mathbf{6} \mathbf{a}-\mathbf{e}$, the ester derivatives $\mathbf{8 a}-\mathbf{c}$, the amide derivatives $\mathbf{9 a}-\mathbf{c}$ and the tricyclic[1,2,4]triazino[2,3-c] quinazolin-3(4H)-one $\mathbf{1 0}$ which is considered as the rigid analog of the chloroacetamido derivative 7 .

In an attempt to probe the similarity between the threedimensional structures of the antiepileptic compounds illustrated in Fig. 1 and selected designed compounds $(\mathbf{6 d}, \mathbf{8 c}, \mathbf{9 b}$, 10), flexible alignment was conducted. Molecular operating environment (MOE)/flexible alignment was employed to automatically generate superpositions of the compounds under investigation with minimal user bias. A common feature of the MOE-generated alignments of the reference compounds (Fig. 3, left panel) was the superimposition of their aromatic groups to generate two distinct hydrophobic domains. In between these two aromatic domains laid the hydrogen bond acceptor group, represented by the amide carbonyl groups which showed perfect maping. The distance of the central carbonyl group to one of the aromatic groups was $4.21 \AA$ and to the other was $4.41 \AA$. The same features were observed with the aligned target compounds i.e., two aromatic domains and a central hydrogen bond acceptor carbonyl group (Fig. 3, right panel); in which the distance between the amide carbonyl group and each of the aromatic areas was 4.30 and $4.55 \AA$. This demonstrated the structural similarity between 

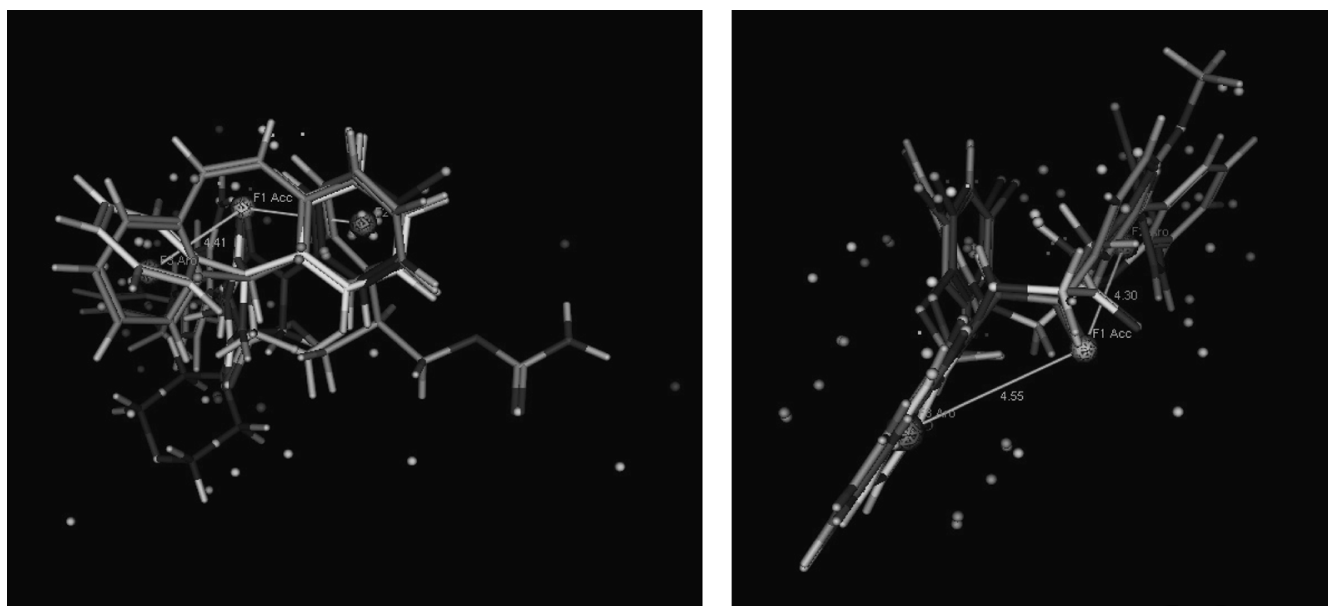

Fig. 3. Flexible Alignment of Reference Compounds (Left Panel) and Test Compounds 6d, 8c, 9b and 10 (Right Panel)

the pharmacophoric features of both reference and target compounds and supported the design of the new compounds. The synthesized compounds were screened in vivo for their anticonvulsant activity through subcutaneous pentylenetetrazole (s.c. PTZ) and MES models. Toxicity of potentially active compounds was assessed by $\mathrm{LD}_{50}$ and neurotoxicity studies.

\section{Results and Discussion}

Chemistry The key starting compound 3-amino-2-(2,4dichlorophenoxy)methyl-3,4-dihydroquinazolin-4-one 4 was prepared from methyl anthranilate $\mathbf{1}$ which was reacted with 2,4-dichlorophenoxyacetyl chloride $\mathbf{2}$ to give the intermediate $\mathbf{3}$ followed by reflux with hydrazine hydrate in $n$-butanol ${ }^{29)}$ (Chart 1). The targeted compounds included the 3- $N$-benzylidine aminoquinazolinone derivatives $\mathbf{5 a}-\mathbf{e}$, their benzylamino congeners $\mathbf{6 a}-\mathbf{e}$, the ester derivatives $\mathbf{8 a}-\mathbf{c}$, the amide derivatives $\mathbf{9 a}-\mathbf{c}$ and the 3,4-annelated quinazolinone: 6-[(2,4-dichlorophenoxy)methyl]-2H-[1,2,4]triazino[2,3-c]quinazolin-3(4H)-one 10 (Charts 2, 3).

The first series of the $3-N$-substituted aminoquinazolinone derivatives $\mathbf{5 a}-\mathbf{e}$ was synthesized by the reaction of the aminoquinazolinone derivative $\mathbf{4}$ with the appropriate benzaldehyde in glacial acetic acid. Evidence for the formation of the target compounds was derived from the IR spectra that revealed the disappearance of the amino stretching vibrations. Moreover, ${ }^{1} \mathrm{H}-\mathrm{NMR}$ spectra revealed the characteristic imine $-\mathrm{N}=\mathrm{CH}$ proton in the range of $\delta 8.83-9.86 \mathrm{ppm}$, in addition to the protons of the (un)substituted benzylidene ring. Reduction of the benzylideneamino derivatives $\mathbf{5 a}-\mathbf{e}$ with sodium borohydride gave compounds $\mathbf{6 a}-\mathbf{e}$. The obtained compounds were characterized by their IR spectra that showed sharp stretching bands in the range of $3433-3271 \mathrm{~cm}^{-1}$ characterestic to the $-\mathrm{NH}-$ group. Furthermore, the structure of the compounds were confirmed from their ${ }^{1} \mathrm{H}-\mathrm{NMR}$ spectra that revealed the absence of the imine proton in addition to the appearance of a signal in the range of $\delta 3.89-5.36 \mathrm{ppm}$ attributed to the methylene $\left(-\mathrm{CH}_{2} \mathrm{NH}-\right)$ protons together with the exchangeable $\mathrm{NH}$ proton. Moreover, mass spectrum of compound $\mathbf{6 b}$ showed the molecular ion peak $[\mathrm{M}]^{+}$at 460 and its isotope $[\mathrm{M}+2]^{+}$peak at 462 .

The intermediate chloroacetamido derivative 7 was prepared from the corresponding 3-aminoquinazolinone $\mathbf{4}$ and chloroacetyl chloride according to the reported procedure. ${ }^{30)}$

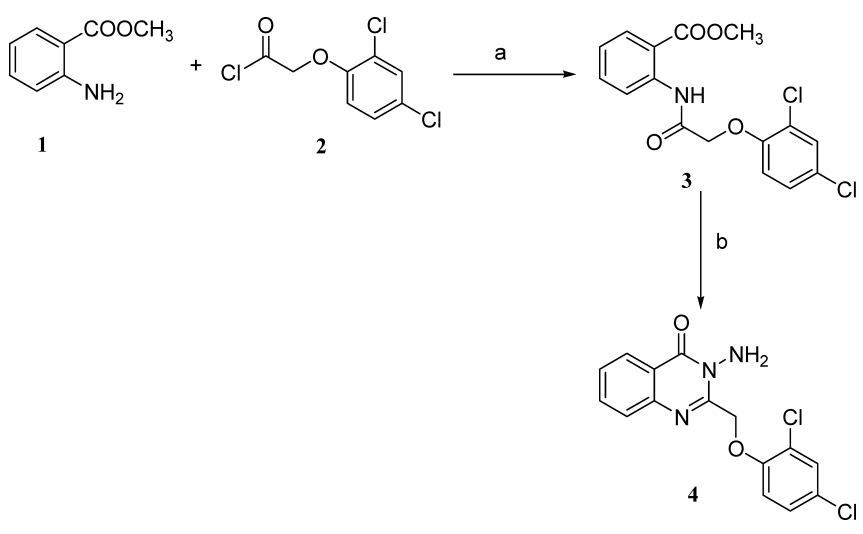

Reagents and conditions: a) dry ether, TEA, stir $24 \mathrm{~h}$ at room temperature; b) hydrazine hydrate ( $c a .100 \%), n$-butanol, reflux $10 \mathrm{~h}$.

Chart 1. Synthesis of Compound 4

The ester derivatives $\mathbf{8 a}-\mathbf{c}$ were obtained via the reaction of the chloro intermediate 7 with the sodium/potassium salt of the appropriate acid in $N, N$-dimethylformamide (DMF). On the other hand, the $N$-substituted amino-acetamide derivatives 9a-c were obtained from the reaction of 7 with the appropriate amine in acetonitrile in the presence of anhydrous potassium carbonate. The target compounds were characterized by spectral analyses especially ${ }^{1} \mathrm{H}-\mathrm{NMR}$ which revealed signals characteristic for the introduced chemical groups. Mass spectrum of compound $\mathbf{8 b}$ demonstrated the characteristic isotopic cluster: $[\mathrm{M}]^{+} 498(3.39)$ and $[\mathrm{M}+2]^{+} 500$ (1.19).

Finally, reacting the chloro intermediate 7 with ammonium acetate in glacial acetic acid gave the 3,4-annelated quinazolinone (triazinoquinazolinone) compound 10. The postulated structure of $\mathbf{1 0}$ was confirmed from its IR spectrum that lacked the band of the quinazolinone carbonyl group that appeared at $1686 \mathrm{~cm}^{-1}$ together with the appearance of a new band at $1718 \mathrm{~cm}^{-1}$ attributed to the carbonyl group of the triazine ring. In addition, the ${ }^{1} \mathrm{H}-\mathrm{NMR}$ spectrum showed a singlet signal at $\delta 5.16 \mathrm{ppm}$ corresponding to the $-\mathrm{CH}_{2}-\mathrm{CO}$ protons of the triazine ring together with the disappearance of the $\mathrm{CH}_{2} \mathrm{Cl}$ protons of the intermediate 7 that appeared at $\delta$ $4.22 \mathrm{ppm}$. In addition, mass spectrum showed isotopic cluster peaks at $[\mathrm{M}]^{+} 375(2.4)$ and $[\mathrm{M}+2]^{+} 377(0.75)$.

Anticonvulsant Activity For the identification of the anti- 


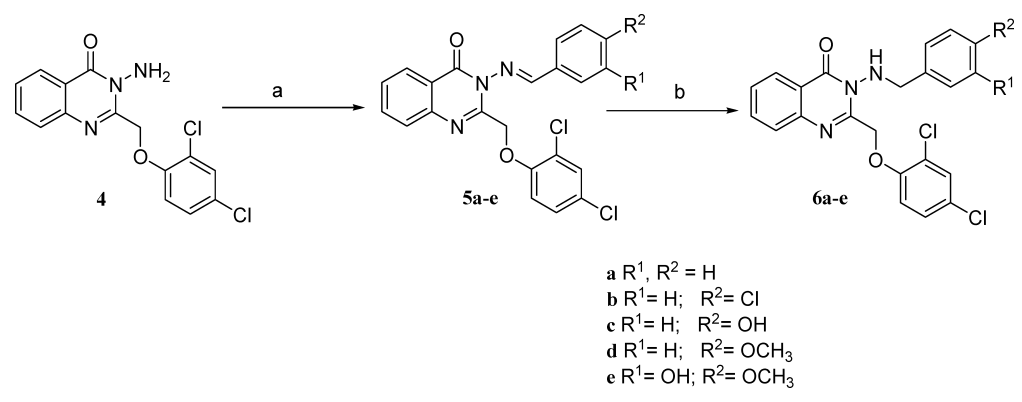

Reagents and conditions: a) appropriate aldehyde, glacial acetic acid, reflux $4 \mathrm{~h}$; b) $\mathrm{NaBH}_{4}$, absolute ethanol, stir overnight at room temperature.

Chart 2. Synthesis of Compounds $5 \mathbf{a}-\mathbf{e}$ and $\mathbf{6 a}-\mathbf{e}$

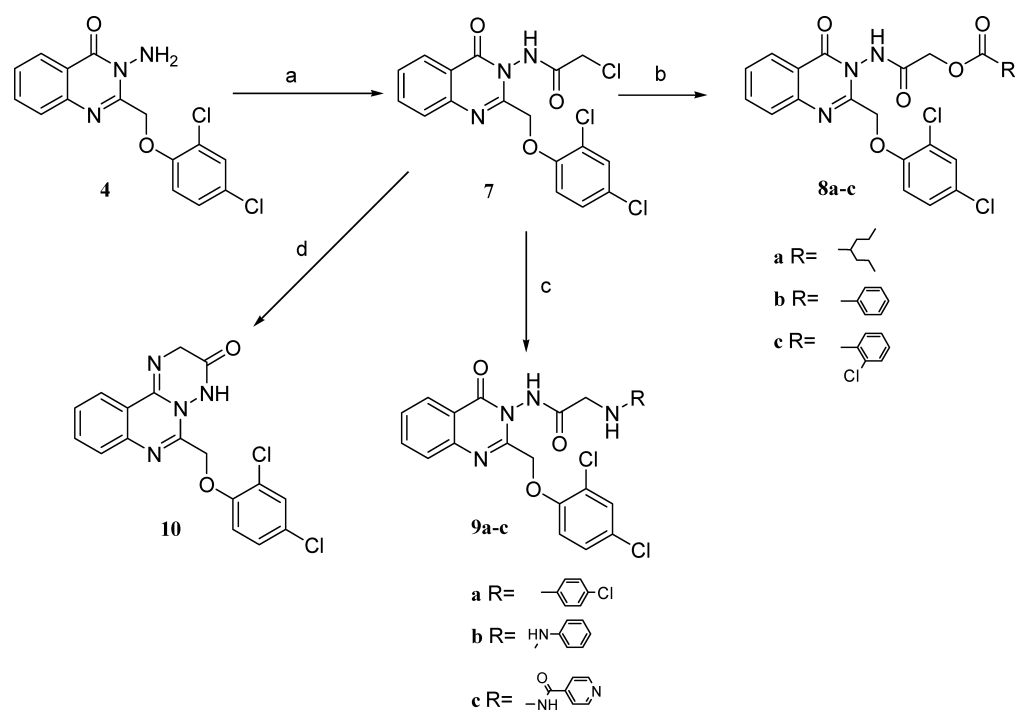

Reagents and conditions: a) chloroacetylcloride, TEA, dry benzene, reflux $4 \mathrm{~h}$; b) sodium/potassium salt of the appropriate acid, DMF, boiling water bath, $6 \mathrm{~h}$; c) appropriate amine, anhydrous $\mathrm{K}_{2} \mathrm{CO}_{3}$, acetonitrile, reflux $8 \mathrm{~h}$; d) anhydrous ammonium acetate, glacial acetic acid, reflux $6 \mathrm{~h}$.

Chart 3. Synthesis of Compounds $\mathbf{8 a}-\mathbf{c}, \mathbf{9 a}-\mathbf{c}$ and $\mathbf{1 0}$

convulsant activity in mice, test compounds were screened by s.c. PTZ and MES models. Compounds found to be active in these seizure models are generally regarded to be significantly useful candidates in the treatment of partial, generalized and even absence seizures. The data regarding the antiepileptic screening of all the compounds are reported in Table 1.

Subcutaneous injection of the convulsant pentylenetetrazole (s.c. PTZ) produces clonic seizures in laboratory animals. The positive results obtained in this test are suggestive of potential clinical utility in generalized absence seizures. Results of s.c. PTZ-induced seizure model showed that the benzylideneamino derivatives $\mathbf{5 a}-\mathbf{e}$ showed approximately $50 \%$ protection. Within this series, although different patterns of substitution were made on the phenyl ring, yet the activity was almost the same for all derivatives. On the other hand, screening results of the reduced derivatives $\mathbf{6 a}-\mathbf{e}$ showed high activity for the $p$-hydroxy and $p$-methoxy compounds $\mathbf{6 c}$ and $\mathbf{6 d}$; and which were also more potent than their parent precursors $\mathbf{5 c}$ and $\mathbf{5 d}$, respectively. A decrease in activity was observed for compounds $\mathbf{6 a}$ and $\mathbf{6 b}$ compared to their precursors $\mathbf{5 a}$ and $\mathbf{5 b}$; while activity was abolished in compound $\mathbf{6 e}$. Concerning the ester derivatives $\mathbf{8 a}-\mathbf{c}$, the most potent compound was the benzoate $\mathbf{8 b}$. Unexpectedly, the valproate ester $\mathbf{8 a}$, showed very low activity suggesting that these compounds did not behave as prodrugs i.e., the valproate moiety was not liberated in vivo or otherwise high activity would be observed. Regarding the amides $9 \mathbf{a}-\mathbf{c}$, activity was the highest with respect to the hydrazide derivative 9c. As per the tricyclic derivative 10, it was the most active among all tested compounds showing $90 \%$ protection. Compound $\mathbf{1 0}$ can be regarded as the rigid analog of 7 , the latter showed only $60 \%$ protection indicating that structure rigidification resulted in improvement of activity. In agreement with the aforementioned pharmacophoric requirements of good anticonvulsant agents, it could be assumed that compounds possessing aryl group at position 3 of the quinazoline core were generally higher in activity than that lacking an aryl moiety e.g. compounds 7 and 8a. Presence of electron donor groups such $\mathrm{OH}$ or $\mathrm{OCH}_{3}$ on the aromatic ring in some compounds such as $\mathbf{5 e}, \mathbf{6 c}$ and $\mathbf{6 d}$ was associated with good activity. The protective dose $50 \%\left(\mathrm{PD}_{50}\right)$ values for the most active compounds in the s.c. PTZ model, 5e, 6c, 6d, 7, $\mathbf{8 b}, 9 \mathbf{c}$ and $\mathbf{1 0}$, in addition to phenobarbitone, were calculated and shown in Table $2 . \mathrm{PD}_{50}$ values were more accurate since dose difference between phenobarbitone and test compounds was taken into consideration. In addition, values were expressed in $\mu \mathrm{mol} / \mathrm{kg}$ to correct for the difference in molecular weights which allowed relevant comparison between the tested compounds. The most active compound was the hydrazide derivative $9 \mathrm{c}\left(\mathrm{PD}_{50} 200.53 \mu \mathrm{mol} / \mathrm{kg}\right)$ followed by the tricyclic compound $10\left(\mathrm{PD}_{50} 233.20 \mu \mathrm{mol} / \mathrm{kg}\right)$. Despite the high $\mathrm{PD}_{50}$ 
Table 1. Anticonvulsant Activity of the Synthesized Compounds in the Pentylenetetrazole (PTZ)-Induced Seizures and Maximal Electroshock (MES) Models

\begin{tabular}{|c|c|c|c|c|}
\hline \multirow[b]{2}{*}{ Compound } & \multirow[b]{2}{*}{ s.c. PTZ test ${ }^{a}$} & \multicolumn{3}{|c|}{ MES test } \\
\hline & & $\begin{array}{l}\text { Mean thresh- } \\
\text { old current } \\
\text { (mA } \mathrm{m} \text { S.E.) }\end{array}$ & $\%$ Protection $^{d)}$ & $\begin{array}{c}\% \text { Relative } \\
\text { potency }^{e}\end{array}$ \\
\hline Control $^{b)}$ & 100 & $2.8 \pm 0.374$ & - & - \\
\hline $\begin{array}{l}\text { Pentylene- } \\
\text { tetrazole }\end{array}$ & 0 & - & - & - \\
\hline $\begin{array}{l}\text { Phenobarbi- } \\
\text { tone }\end{array}$ & 100 & - & - & - \\
\hline Phenytoin & - & $7.8 \pm 0.374^{c)}$ & 178.5 & - \\
\hline $5 \mathbf{a}$ & 50 & $5.8 \pm 0.583^{c)}$ & 107.1 & 59.9 \\
\hline $5 b$ & 40 & $3.8 \pm 0.490$ & 35.7 & 20.0 \\
\hline $5 c$ & 40 & $5.0 \pm 0.447$ & 78.6 & 44.0 \\
\hline $5 d$ & 50 & $7.4 \pm 0.678^{c)}$ & 164.3 & 92.0 \\
\hline $5 e$ & 60 & $6.0 \pm 0.447^{c)}$ & 114.3 & 64.0 \\
\hline $6 \mathbf{a}$ & 20 & $6.8 \pm 0.490^{c)}$ & 142.9 & 80.1 \\
\hline $6 b$ & 30 & $8.0 \pm 0.837^{c)}$ & 185.7 & 104.0 \\
\hline $6 c$ & 70 & $6.2 \pm 0.374^{c)}$ & 121.4 & 68.0 \\
\hline $6 d$ & 60 & $8.2 \pm 0.663^{c)}$ & 192.9 & 108.1 \\
\hline $6 e$ & 0 & $7.6 \pm 0.510^{c)}$ & 171.4 & 96.0 \\
\hline 7 & 60 & $5.3 \pm 0.18^{c)}$ & 89.3 & 50.0 \\
\hline $8 \mathbf{a}$ & 10 & $7.4 \pm 0.245^{c)}$ & 164.3 & 92.0 \\
\hline $8 b$ & 60 & $6.6 \pm 0.245$ & 135.7 & 76.0 \\
\hline $8 c$ & 0 & $8.2 \pm 0.200^{c)}$ & 192.9 & 108.1 \\
\hline $9 \mathbf{a}$ & 30 & $7.0 \pm 0.447^{c)}$ & 150.0 & 84.0 \\
\hline $9 b$ & 20 & $8.4 \pm 0.400^{c)}$ & 200.0 & 112.0 \\
\hline $9 c$ & 70 & $6.8 \pm 0.490^{c)}$ & 142.9 & 80.1 \\
\hline 10 & 90 & $6.8 \pm 0.487^{c)}$ & 142.9 & 80.1 \\
\hline
\end{tabular}

a) Values represent $\%$ protection from PTZ-induced seizures. b) This represents a negative control group receiving only the vehicle $(2 \%$ Tween 80$)$. c) Values are statistically significant $(p<0.05)$ from control group using one way ANOVA followed by Turkey's as post tests. $d$ ) \% protection was calculated as the percentage of the difference between the threshold current of control and test compound to the threshold current of control. e) \% relative potency was calculated as the percentage of the value of $\%$ protection of test compound to that of phenytoin.

values for the tested compounds compared to phenobarbitone (approximately 3-4 times), yet this could be outweighed by the much higher safety profile of these compounds as revealed by the results of the $\mathrm{LD}_{50}$ and the therapeutic index (Table 3).

The MES is a model for generalized tonic-clonic seizures and provides a hint of a compound's ability to stop seizure spread when all neuronal circuits in the brain are maximally active. These seizures are extremely reproducible and are electro physiologically reliable with human seizures. Activity of the tested compounds in the MES model was markedly higher than that observed in the s.c. PTZ model suggesting the potential usefulness of these compounds in generalized tonic-clonic rather than in absence convulsions. Three of the tested compounds were almost equipotent to phenytoin: $\mathbf{5 d}, \mathbf{6 e}$ and $\mathbf{8 a}$; and four compounds were more potent than phenytoin, namely; 6b, 6d, 8c and 9b. Concerning the ylidene compounds $\mathbf{5 a}-\mathbf{e}$ and their reduced derivatives $\mathbf{6 a}-\mathbf{e}$, it was observed that activity increased in compounds $\mathbf{6 a}-\mathbf{e}$ compared to their precursors 5a-e, with the $p$-methoxyphenyl derivatives $(\mathbf{5 d}, \mathbf{6 d})$ being the most active. Within the ester series $\mathbf{8 a}-\mathbf{c}$, the most active compound was the 2-chlorobenzoate $\mathbf{8 c}$ followed by the valproate derivative $\mathbf{8 a}$. The phenyl hydrazine derivative $\mathbf{9 b}$ was the most active in the amine series $\mathbf{9 a}-\mathbf{c}$. Again, the tricyclic derivative 10, which could be considered the rigid analog of compound 7, showed higher activity than 7 indicating that
Table 2. $\mathrm{PD}_{50}$ Values for Phenobarbitone and Compounds 5e, 6c, 6d, 7, $8 b, 9 c, 10$

\begin{tabular}{|c|c|c|c|}
\hline Compound & Dose $(\mathrm{mg} / \mathrm{kg})$ & $\%$ Protection $^{a)}$ & $\begin{array}{c}\mathrm{PD}_{50} \mathrm{mg} / \mathrm{kg} \\
(\mu \mathrm{mol} / \mathrm{kg})\end{array}$ \\
\hline \multirow[t]{3}{*}{ Phenobarbitone } & 10 & 40 & $14.44(62.18)$ \\
\hline & 20 & 60 & \\
\hline & 30 & 100 & \\
\hline \multirow[t]{3}{*}{$5 e$} & 50 & 20 & $114.13(242.67)$ \\
\hline & 100 & 60 & \\
\hline & 200 & 80 & \\
\hline \multirow[t]{3}{*}{$6 c$} & 50 & 40 & $105.00(237.40)$ \\
\hline & 100 & 70 & \\
\hline & 200 & 80 & \\
\hline \multirow[t]{3}{*}{ 6d } & 50 & 30 & $122.10(267.58)$ \\
\hline & 100 & 60 & \\
\hline & 200 & 70 & \\
\hline \multirow[t]{3}{*}{7} & 50 & 20 & $114.13(284.97)$ \\
\hline & 100 & 60 & \\
\hline & 200 & 80 & \\
\hline \multirow[t]{3}{*}{$8 b$} & 50 & 30 & $122.10(245.03)$ \\
\hline & 100 & 60 & \\
\hline & 200 & 70 & \\
\hline \multirow[t]{3}{*}{$9 \mathrm{c}$} & 50 & 50 & $102.94(200.53)$ \\
\hline & 100 & 70 & \\
\hline & 200 & 80 & \\
\hline \multirow[t]{3}{*}{10} & 50 & 60 & $87.50(233.20)$ \\
\hline & 100 & 90 & \\
\hline & 200 & 90 & \\
\hline
\end{tabular}

a) Data analyzed by one way ANOVA $(n=10)$, all compounds were significantly different from control and from phenobarbitone sodium using Student's $t$-test, $p<0.05$.

Table 3. $\mathrm{LD}_{50}$ and Therapeutic Index of Phenobarbitone and Compounds 5e, 6c, 9c, 10

\begin{tabular}{lcc}
\hline \hline Compound & $\mathrm{LD}_{50}(\mu \mathrm{mol} / \mathrm{kg})$ & Therapeutic index \\
\hline Phenobarbitone & 263 & 4.23 \\
$\mathbf{5 e}$ & $>3000$ & $>12.36$ \\
$\mathbf{6 c}$ & $>3000$ & $>12.64$ \\
$\mathbf{9 c}$ & $>3000$ & $>14.96$ \\
$\mathbf{1 0}$ & $>3000$ & $>12.86$ \\
\hline
\end{tabular}

Table 4. Neurotoxicity Screening of Phenytoin and Compounds $\mathbf{6 b}, \mathbf{6 d}$, $8 \mathbf{c}, 9 \mathbf{b}^{a)}$

\begin{tabular}{lcc}
\hline \hline Compound & $0.5 \mathrm{~h}$ & $4 \mathrm{~h}$ \\
\hline Phenytoin & 100 & 100 \\
6b & 300 & 300 \\
$\mathbf{6 d}$ & - & - \\
$\mathbf{8 c}$ & 100 & - \\
$\mathbf{9 b}$ & 300 & 300
\end{tabular}

a) Doses of 30,100 and $300 \mathrm{mg} / \mathrm{kg}$ were administered intraperitoneally. The figures indicate the minimal dose required to cause neurotoxicity in $50 \%$ or more of the animals at the specified time.

structural rigidification favored its anticonvulsant activity. Finally, it could be observed that some compounds that were almost inactive in the s.c. PTZ model such as $\mathbf{6 b}, \mathbf{6 e}, \mathbf{8 a}, \mathbf{8 c}$ and 9b were, on the other hand, highly active in the MES model. At the same time, few compounds such as $\mathbf{9 c}$ and $\mathbf{1 0}$ were effective against seizures induced in both models.

Promising compounds in this study, specifically compounds showing potency higher than phenytoin in the MES model, 
$\mathbf{6 b}, \mathbf{6 d}, \mathbf{8 c}$ and $\mathbf{9 b}$, were selected for neurotoxicity assessment using the standardized rotarod test. Compound 8c showed neurotoxicity at $100 \mathrm{mg} / \mathrm{kg}$ similar to phenytoin. On the other hand, compounds $\mathbf{6 b}$ and $\mathbf{9 b}$ showed neurotoxicity at $300 \mathrm{mg} /$ $\mathrm{kg}$ and compound $\mathbf{6 d}$ did not show any signs of neurotoxicity making them safer than phenytoin (Table 4).

\section{Conclusion}

New 2,3-disubstituted quinazolinones and a 3,4-annelated quinazoline derivative featuring the pharmacophoric elements of antiepileptic drugs were designed and synthesized for preliminary anticonvulsant screening. Synthesized compounds were screened for their anticonvulsant activity using the s.c. PTZ and MES models. LD $_{50}$ for the most active compounds was calculated. Results in the s.c. PTZ test were not much satisfactory; the most active compound was the 9c having a $\mathrm{PD}_{50}$ of $200.53 \mu \mathrm{mol} / \mathrm{kg}\left(\mathrm{PD}_{50}\right.$ of phenobarbitone $=62.18 \mu \mathrm{mol} /$ $\mathrm{kg}$ ). Nevertheless, this low potency is outweighed by the much higher safety profile $\left(\mathrm{LD}_{50}>3000 \mu \mathrm{mol} / \mathrm{kg}\right)$. In the MES screening, seven compounds were equal to or more active than phenytoin; the most potent one was $\mathbf{9 b}$. Compounds more potent than phenytoin in the MES model, namely $\mathbf{6 b}, \mathbf{6 d}$ and 9b were advantageously less neurotoxic than phenytoin. In general, the overall results revealed that the test compounds were more effective in the MES model than in the chemoshock test suggesting the potential usefulness of these compounds in generalized tonic-clonic rather than in absence convulsions. Few compounds such as $\mathbf{9 c}$ and $\mathbf{1 0}$ were effective in both models.

\section{Experimental}

Chemistry Melting points were uncorrected and were carried out by open capillary tube method using IA 9100 MK-Digital Melting Point Apparatus. Elemental microanalyses were carried out on Heraew and Vario El III (elementar), CHNS analyzer (Germany) at the Microanalytical Center, Faculty of Science, Cairo University. Infrared spectra were made on Bruker Vector 22 (Japan), infrared spectrophotometers and were expressed in wave number $\left(\mathrm{cm}^{-1}\right)$ using potassium bromide disc. ${ }^{1} \mathrm{H}-\mathrm{NMR}$ spectra were recorded on a Varian Mercury VX-300 NMR spectrometer at $300 \mathrm{MHz}$ and ${ }^{13} \mathrm{C}-\mathrm{NMR}$ were recorded at $75 \mathrm{MHz}$ in the specified solvent. Chemical shifts were reported on the d scale and were related to that of the solvent and $J$ values are given in Hz. Mass spectra were recorded on Shimadzu Qp-2010 plus, at $70 \mathrm{eV}$ (EI). IUPAC chemical nomenclature were assigned using CS Chemdraw ultra version 5.0. Thin layer chromatography was performed using MachereyeNagel Alugram Sil G/UV254 silica gel plates and petroleum ether-ethyl acetate $(9: 1)$ as the eluting system.

General Procedure for the Synthesis of Compounds (5ae) A mixture of 3-amino-2-(2,4-dichlorophenoxymethyl)quinazolin-4(3H)-one $4(0.34 \mathrm{~g} ; 1 \mathrm{mmol})$ and the appropriate benzaldehyde $(1.1 \mathrm{mmol})$ in glacial acetic acid $(20 \mathrm{~mL})$ was heated under reflux for $4 \mathrm{~h}$. The reaction mixture was poured on ice-water and the separated solid was filtered off, washed with aqueous ethanol and crystallized from ethanol.

3-Benzylidenamino-2-[(2,4-dichlorophenoxy)methyl]quinazolin-4(3H)-one (5a): mp $190-192^{\circ} \mathrm{C}$; yield $81 \%$. ${ }^{1} \mathrm{H}-\mathrm{NMR}\left(\mathrm{CDCl}_{3}\right) \delta: 5.42\left(2 \mathrm{H}, \mathrm{s}, \mathrm{CH}_{2} \mathrm{O}\right), 7.06-7.92(11 \mathrm{H}, \mathrm{m}$, aromatic $\mathrm{H}), 8.34(1 \mathrm{H}, \mathrm{d}, J=7.8 \mathrm{~Hz}, \mathrm{C} 5-\mathrm{H}$ quinazoline), 9.17 $(1 \mathrm{H}, \mathrm{s}, \mathrm{N}=\mathrm{CH}) . \mathrm{IR} \mathrm{cm}{ }^{-1}: 3063(\mathrm{CH}$ aromatic), 2919 (CH ali- phatic), 1688 (CO), 767 (C-Cl). Anal. Calcd for $\mathrm{C}_{22} \mathrm{H}_{15} \mathrm{Cl}_{2} \mathrm{~N}_{3} \mathrm{O}_{2}$ (424.28): C, 62.28; H, 3.56; N, 9.90. Found: C, 62.56; H, 3.80; N, 9.69 .

3-(4-Chlorobenzylidenamino)-2-[(2,4-dichlorophenoxy)methyl]quinazolin-4(3H)-one $(\mathbf{5 b})$ : $\mathrm{mp} 177-179^{\circ} \mathrm{C}$; yield $80 \%$. ${ }^{1} \mathrm{H}-\mathrm{NMR}\left(\mathrm{CDCl}_{3}\right) \delta: 5.39\left(2 \mathrm{H}, \mathrm{s}, \mathrm{CH}_{2} \mathrm{O}\right), 7.03-7.81(10 \mathrm{H}, \mathrm{m}$, aromatic $\mathrm{H}), 8.33(1 \mathrm{H}, \mathrm{d}, J=7.8 \mathrm{~Hz}, \mathrm{C} 5-\mathrm{H}$ quinazoline), 9.17 $(1 \mathrm{H}, \mathrm{s}, \mathrm{N}=\mathrm{CH}) . \mathrm{MS} \mathrm{m} / \mathrm{z}(\%): \mathrm{M}^{+} 458(3.11),(\mathrm{M}+2)^{+} 460$ (1.03), 285 (100). IR cm ${ }^{-1}: 3071$ (CH aromatic), 2923 (CH aliphatic), 1687 (CO), $766(\mathrm{C}-\mathrm{Cl})$. Anal. Calcd for $\mathrm{C}_{22} \mathrm{H}_{14} \mathrm{Cl}_{3} \mathrm{~N}_{3} \mathrm{O}_{2}$ (458.72): C, 57.60; H, 3.08; N, 9.16. Found: C, 57.94; H, 3.31; $\mathrm{N}, 9.26$.

2-[(2,4-Dichlorophenoxy)methyl]-3-(4-hydroxybenzylideneamino)quinazolin-4(3H)-one $(\mathbf{5 c})$ : $\mathrm{mp} 160-161^{\circ} \mathrm{C}$; yield $77 \%$. ${ }^{1} \mathrm{H}-\mathrm{NMR}\left(\mathrm{CDCl}_{3}\right) \quad \delta: 5.44\left(2 \mathrm{H}, \mathrm{s}, \mathrm{CH}_{2} \mathrm{O}\right), 6.86-7.88$ $(10 \mathrm{H}, \mathrm{m}$, aromatic $\mathrm{H}), 8.30(1 \mathrm{H}, \mathrm{d}, J=8.1 \mathrm{~Hz}, \mathrm{C} 5-\mathrm{H}$ quinazoline), $8.36\left(1 \mathrm{H}, \mathrm{s}, \mathrm{OH}\right.$, exchangeable with $\left.\mathrm{D}_{2} \mathrm{O}\right), 9.86(1 \mathrm{H}, \mathrm{s}$, $\mathrm{N}=\mathrm{CH})$. IR cm $\mathrm{cm}^{-1}: 3444(\mathrm{OH}), 3076(\mathrm{CH}$ aromatic), 2954, 2922 (CH aliphatic), 1669 (CO), $772(\mathrm{C}-\mathrm{Cl})$. Anal. Calcd for $\mathrm{C}_{22} \mathrm{H}_{15} \mathrm{Cl}_{2} \mathrm{~N}_{3} \mathrm{O}_{3}$ (440.28): C, 60.02; H, 3.43; N, 9.54. Found: C, 59.65; H, 3.90; N, 9.90 .

2-[(2,4-Dichlorophenoxy)methyl]-3-(4-methoxybenzylideneamino)quinazolin-4(3H)-one $(\mathbf{5 d})$ : $\mathrm{mp} 205-208^{\circ} \mathrm{C}$; yield 80\%. ${ }^{1} \mathrm{H}-\mathrm{NMR}\left(\mathrm{CDCl}_{3}\right) \delta: 3.89\left(3 \mathrm{H}, \mathrm{s}, \mathrm{OCH}_{3}\right), 5.39(2 \mathrm{H}, \mathrm{s}$, $\left.\mathrm{CH}_{2} \mathrm{O}\right), 6.93-7.87(10 \mathrm{H}, \mathrm{m}$, aromatic $\mathrm{H}), 8.33(1 \mathrm{H}, \mathrm{d}, J=7.8 \mathrm{~Hz}$, C5-H quinazoline), $8.97(1 \mathrm{H}, \mathrm{s}, \mathrm{N}=\mathrm{CH}) .{ }^{13} \mathrm{C}-\mathrm{NMR}\left(\mathrm{CDCl}_{3}\right)$ $\delta$ : $55.6\left(\mathrm{OCH}_{3}\right), 65.1\left(\mathrm{OCH}_{2}\right), 115.2-135.0$ (aromatic $\left.\mathrm{Cs}\right), 140.8$ $(\mathrm{CH}=\mathrm{N}), 143.5$ (C-8a quinazoline), 145.2 (C-1 phenoxy), 158.3 ( $\mathrm{C}=\mathrm{O}$ quinazoline), 162.8 (C-4 benzylidine), 164.0 (C2-quinazoline). IR cm ${ }^{-1}$ : 3073 ( $\mathrm{CH}$ aromatic), $2918(\mathrm{CH}$ aliphatic), $1678(\mathrm{CO}), 768(\mathrm{C}-\mathrm{Cl})$. Anal. Calcd for $\mathrm{C}_{23} \mathrm{H}_{17} \mathrm{Cl}_{2} \mathrm{~N}_{3} \mathrm{O}_{3}$ (454.31): C, 60.81; H, 3.77; N, 9.25. Found: C, 60.47; H, 3.41; $\mathrm{N}, 9.45$.

2-[(2,4-Dichlorophenoxy)methyl]-3-(3-hydroxy-4-methoxybenzylideneamino)quinazolin-4(3H)-one $(\mathbf{5 e})$ : $\mathrm{mp} 174-175^{\circ} \mathrm{C}$; yield $83 \%$. ${ }^{1} \mathrm{H}-\mathrm{NMR}\left(\mathrm{DMSO}-d_{6}\right) \delta: 3.76\left(3 \mathrm{H}, \mathrm{s}, \mathrm{OCH}_{3}\right), 5.40$ $\left(2 \mathrm{H}, \mathrm{s}, \mathrm{CH}_{2} \mathrm{O}\right), 6.87-7.84(9 \mathrm{H}, \mathrm{m}$, aromatic $\mathrm{H}), 8.14(1 \mathrm{H}, \mathrm{d}$, $J=7.5 \mathrm{~Hz}, \mathrm{C} 5-\mathrm{H}$ quinazoline), $8.83(1 \mathrm{H}, \mathrm{s}, \mathrm{N}=\mathrm{CH}), 11.07(1 \mathrm{H}$, $\mathrm{s}, \mathrm{OH}$, exchangeable with $\left.\mathrm{D}_{2} \mathrm{O}\right) . \mathrm{IR} \mathrm{cm}^{-1}: 3309(\mathrm{OH}), 3072$ (CH aromatic), 2922 ( $\mathrm{CH}$ aliphatic), $1678(\mathrm{CO}), 770(\mathrm{C}-\mathrm{Cl})$. Anal. Calcd for $\mathrm{C}_{23} \mathrm{H}_{17} \mathrm{Cl}_{2} \mathrm{~N}_{3} \mathrm{O}_{4}$ (470.30): C, 58.74; H, 3.64; N, 8.93. Found: C, 58.55; H, 3.51; N, 9.12.

General Procedure for the Synthesis of Compounds (6ae) To a stirred solution of $\mathbf{5 a}-\mathbf{e}(10 \mathrm{mmol})$ in absolute ethanol $(20 \mathrm{~mL})$, sodium borohydride $(0.2 \mathrm{~g}, 5 \mathrm{mmol})$ was added portionwise and stirring was continued for $1 \mathrm{~h}$. The reaction mixture was left to stand overnight at room temperature; then diluted with water and the separated crystals were filtered off, washed with water and recrystallized from aqueous ethanol.

3-Benzylamino-2-[(2,4-dichlorophenoxy)methyl]quinazolin-4(3H)-one (6a): mp $190-191^{\circ} \mathrm{C}$; yield $60 \%$. ${ }^{1} \mathrm{H}-\mathrm{NMR}\left(\mathrm{CDCl}_{3}\right) \delta: 4.17\left(2 \mathrm{H}, \mathrm{d}, J=6.5 \mathrm{~Hz}, \mathrm{CH}_{2} \mathrm{NH}\right), 5.38$ $\left(2 \mathrm{H}, \mathrm{s}, \mathrm{CH}_{2} \mathrm{O}\right), 7.02-7.83(11 \mathrm{H}, \mathrm{m}$, aromatic $\mathrm{H}), 8.34(1 \mathrm{H}, \mathrm{d}$, $J=7.5 \mathrm{~Hz}$, C5-H quinazoline), 9.14 (1H, brs, NH exchangeable with $\left.\mathrm{D}_{2} \mathrm{O}\right)$. IR cm $\mathrm{cm}^{-1}: 3433(\mathrm{NH}) ; 3063$ ( $\mathrm{CH}$ aromatic), 2921 (CH aliphatic), $1686(\mathrm{CO}), 766(\mathrm{C}-\mathrm{Cl})$. Anal. Calcd for $\mathrm{C}_{22} \mathrm{H}_{17} \mathrm{Cl}_{2} \mathrm{~N}_{3} \mathrm{O}_{2}$ (426.30): C, 61.98; H, 4.02; N, 9.86. Found: $\mathrm{C}$, 61.60; H, 4.17; N, 9.80.

3-(4-Chlorobenzylamino)-2-[(2,4-dichlorophenoxy)methyl]quinazolin-4(3H)-one (6b): mp $170-171^{\circ} \mathrm{C}$; yield $55 \%$. ${ }^{1} \mathrm{H}-\mathrm{NMR}\left(\mathrm{CDCl}_{3}\right) \delta: 4.27\left(2 \mathrm{H}, \mathrm{d}, J=6.3 \mathrm{~Hz}, \mathrm{CH}_{2} \mathrm{NH}\right), 5.29$ 
$\left(2 \mathrm{H}, \mathrm{s}, \mathrm{CH}_{2} \mathrm{O}\right), 7.02-7.82(11 \mathrm{H}, \mathrm{m}, 10$ aromatic $\mathrm{H}$ and $\mathrm{NH}$ exchangeable with $\left.\mathrm{D}_{2} \mathrm{O}\right), 8.32(1 \mathrm{H}, \mathrm{d}, J=7.5 \mathrm{~Hz}, \mathrm{C} 5-\mathrm{H}$ quinazoline). ${ }^{13} \mathrm{C}-\mathrm{NMR}\left(\mathrm{CDCl}_{3}\right) \delta: 52.6\left(-\mathrm{CH}_{2} \mathrm{NH}-\right), 65.8\left(\mathrm{OCH}_{2}\right)$, 118.9-137.0 (aromatic Cs), 142.7 (C-8a quinazoline), 145.5 (C-1 phenoxy), 158.6 ( $\mathrm{C}=\mathrm{O}$ quinazoline), 164.1 (C-2-quinazoline). IR cm ${ }^{-1}: 3271(\mathrm{NH}) ; 3065$ (CH aromatic), 2918 (CH aliphatic), 1685 (CO), 771 (C-Cl). MS: $m / z(\%): \mathrm{M}^{+} 460(1.90)$; $[\mathrm{M}+2]^{+}$ 462 (0.64), 125 (100). Anal. Calcd for $\mathrm{C}_{22} \mathrm{H}_{16} \mathrm{Cl}_{3} \mathrm{~N}_{3} \mathrm{O}_{2}$ (460.74): C, 57.35; H, 3.50; N, 9.12. Found: C, 57.75; H, 3.85; N, 9.15.

2-[(2,4-Dichlorophenoxy)methyl]-3-(4-hydroxybenzylamino)quinazolin-4(3H)-one $(6 \mathbf{c})$ : $\mathrm{mp} 200-202^{\circ} \mathrm{C}$; yield $55 \%$. ${ }^{1} \mathrm{H}-\mathrm{NMR}\left(\mathrm{CDCl}_{3}\right) \delta: 5.25\left(2 \mathrm{H}, \mathrm{d}, J=6.5 \mathrm{~Hz}, \mathrm{CH}_{2} \mathrm{NH}\right), 5.36$ $\left(2 \mathrm{H}, \mathrm{s}, \mathrm{CH}_{2} \mathrm{O}\right), 6.85-7.80(12 \mathrm{H}, \mathrm{m}, 10$ aromatic $\mathrm{H}, \mathrm{NH}$ and $\mathrm{OH}$ exchangeable with $\left.\mathrm{D}_{2} \mathrm{O}\right), 8.34(1 \mathrm{H}, \mathrm{d}, J=7.8 \mathrm{~Hz}, \mathrm{C} 5-\mathrm{H}$ quinazoline). IR cm ${ }^{-1}: 3447(\mathrm{OH}), 3420(\mathrm{NH}), 3102(\mathrm{CH}$ aromatic),2959, 2922 (CH aliphatic), 1687 (CO), 770 (C-Cl). Anal. Calcd for $\mathrm{C}_{22} \mathrm{H}_{17} \mathrm{Cl}_{2} \mathrm{~N}_{3} \mathrm{O}_{3}$ (442.29): C, 59.74; H, 3.87; N, 9.50. Found: C, 59.72; H, 4.10; N, 9.36.

2-[(2,4-Dichlorophenoxy)methyl]-3-(4-methoxybenzylamino)quinazolin-4(3H)-one $(\mathbf{6 d})$ : $\mathrm{mp} 170-172^{\circ} \mathrm{C}$; yield $50 \%$. ${ }^{1} \mathrm{H}-\mathrm{NMR}\left(\mathrm{CDCl}_{3}\right) \delta: 3.81\left(3 \mathrm{H}, \mathrm{s}, \mathrm{OCH}_{3}\right), 3.89\left(2 \mathrm{H}, \mathrm{d}, \mathrm{CH}_{2} \mathrm{NH}\right.$, $J=6.5 \mathrm{~Hz}), 5.38\left(2 \mathrm{H}, \mathrm{s}, \mathrm{CH}_{2} \mathrm{O}\right), 6.85-7.78(10 \mathrm{H}, \mathrm{m}$, aromatic $\mathrm{H}), 8.33(1 \mathrm{H}, \mathrm{d}, J=7.8 \mathrm{~Hz}, \mathrm{C} 5-\mathrm{H}$ quinazoline $), 8.97(1 \mathrm{H}, \mathrm{brs}$, $\mathrm{NH}$ exchangeable with $\left.\mathrm{D}_{2} \mathrm{O}\right) . \mathrm{IR} \mathrm{cm} \mathrm{cm}^{-1}: 3422(\mathrm{NH}), 3067(\mathrm{CH}$ aromatic), 2924 (CH aliphatic), 1681 (CO), 767 (C-Cl). Anal. Calcd for $\mathrm{C}_{23} \mathrm{H}_{19} \mathrm{Cl}_{2} \mathrm{~N}_{3} \mathrm{O}_{3}$ (456.32): C, 60.54; H, 4.20; N, 9.21. Found: C, 60.65; H, 4.54; N, 9.31.

2-[(2,4-Dichlorophenoxy)methyl]-3-(3-hydroxy-4-methoxybenzylamino)quinazolin-4(3H)-one $(6 \mathbf{e})$ : $\mathrm{mp} 180-183^{\circ} \mathrm{C}$; yield $60 \%$. ${ }^{1} \mathrm{H}-\mathrm{NMR}\left(\mathrm{CDCl}_{3}\right) \delta: 3.89\left(3 \mathrm{H}, \mathrm{s}, \mathrm{OCH}_{3}\right), 5.11(2 \mathrm{H}, \mathrm{d}$, $\left.J=6.5 \mathrm{~Hz}, \mathrm{CH}_{2} \mathrm{NH}\right), 5.37\left(2 \mathrm{H}, \mathrm{s}, \mathrm{CH}_{2} \mathrm{O}\right), 6.96-7.77(9 \mathrm{H}, \mathrm{m}$, aromatic $\mathrm{H}), 8.25(1 \mathrm{H}, \mathrm{d}, J=7.8 \mathrm{~Hz}, \mathrm{C} 5-\mathrm{H}$ quinazoline), 8.33 $\left(1 \mathrm{H}\right.$, brs, NH exchangeable with $\left.\mathrm{D}_{2} \mathrm{O}\right), 8.90(1 \mathrm{H}, \mathrm{s}, \mathrm{OH}$ exchangeable with $\mathrm{D}_{2} \mathrm{O}$ ). IR cm ${ }^{-1}: 3311$ (br band, $\mathrm{OH}, \mathrm{NH}$ ), 3067 (CH aromatic), 2933 (CH aliphatic), $1636(\mathrm{CO}), 753(\mathrm{C}-\mathrm{Cl})$. Anal. Calcd for $\mathrm{C}_{23} \mathrm{H}_{19} \mathrm{Cl}_{2} \mathrm{~N}_{3} \mathrm{O}_{4}$ (472.32): C, 58.49; H, 4.05; N, 8.90. Found: C, 58.39; H, 4.31; N, 8.64.

General Procedure for the Synthesis of Compounds (8ac) A mixture of $7(0.41 \mathrm{~g}, 1 \mathrm{mmol})$ and the sodium/potassium salt of the appropriate acid $(1.1 \mathrm{mmol})$ in DMF $(20 \mathrm{~mL})$ were heated in a boiling water bath for $6 \mathrm{~h}$. The reaction mixture was poured onto ice-cold water. The separated solid was filtered off, washed with water, dried and recrystallized from ethanol.

[2-(2,4-Dichlorophenoxy)methyl-4-oxo-4H-quinazolin-3ylcarbamoyl]methyl 2-Propyl-pentanoate (8a): $\mathrm{mp} 160-162^{\circ} \mathrm{C}$; yield 55\%. ${ }^{1} \mathrm{H}-\mathrm{NMR}\left(\mathrm{CDCl}_{3}\right) \quad \delta: 0.87(6 \mathrm{H}, \mathrm{t}, J=7.2 \mathrm{~Hz}, 2$ $\left.\mathrm{CHCH}_{2} \mathrm{CH}_{2} \mathrm{CH}_{3}\right), 1.25\left(4 \mathrm{H}, \mathrm{m}, 2 \mathrm{CHCH}_{2} \mathrm{CH}_{2} \mathrm{CH}_{3}\right), 1.58(4 \mathrm{H}$, q, $\left.J=6.9 \mathrm{~Hz}, \mathrm{CHCH}_{2} \mathrm{CH}_{2} \mathrm{CH}_{3}\right), 2.48\left(1 \mathrm{H}, \mathrm{m}, \mathrm{CHCH}_{2} \mathrm{CH}_{2} \mathrm{CH}_{3}\right)$, $4.82\left(2 \mathrm{H}, \mathrm{s}, \mathrm{CH}_{2} \mathrm{CO}\right), 5.19\left(2 \mathrm{H}, \mathrm{s}, \mathrm{CH}_{2} \mathrm{O}\right) ; 7.07-8.00(6 \mathrm{H}, \mathrm{m}$, aromatic $\mathrm{H}), 8.20(1 \mathrm{H}, \mathrm{d}, J=6.8 \mathrm{~Hz}, \mathrm{C} 5-\mathrm{H}$ quinazoline), 9.22 $\left(1 \mathrm{H}, \mathrm{s}, \mathrm{NH}\right.$ exchangeable with $\left.\mathrm{D}_{2} \mathrm{O}\right) . \mathrm{IR} \mathrm{cm}^{-1}: 3487(\mathrm{NH}), 3166$ (CH aromatic), 2945 (CH aliphatic), 1726 (COs), $764(\mathrm{C}-\mathrm{Cl})$. Anal. Calcd for $\mathrm{C}_{25} \mathrm{H}_{27} \mathrm{Cl}_{2} \mathrm{~N}_{3} \mathrm{O}_{5}$ (520.40): C, 57.70; H, 5.23; N, 8.07. Found: C, 57.60; H, 5.30; N, 8.26.

[2-(2,4-Dichlorophenoxy)methyl-4-oxo-4H-quinazolin-3ylcarbamoyl]methyl Benzoate $(\mathbf{8 b})$ : $\mathrm{mp} 165-168^{\circ} \mathrm{C}$; yield $65 \%$. ${ }^{1} \mathrm{H}-\mathrm{NMR}\left(\mathrm{CDCl}_{3}\right) \delta: 5.10\left(2 \mathrm{H}, \mathrm{s}, \mathrm{CH}_{2} \mathrm{CO}\right), 5.36\left(2 \mathrm{H}, \mathrm{s}, \mathrm{CH}_{2} \mathrm{O}\right)$, $7.02-7.99(11 \mathrm{H}, \mathrm{m}$, aromatic $\mathrm{H}), 8.27(1 \mathrm{H}, \mathrm{d}, J=6.6 \mathrm{~Hz}$, C5-H quinazoline), $8.83(1 \mathrm{H}, \mathrm{s}, \mathrm{NH}$ exchangeable with $\left.\mathrm{D}_{2} \mathrm{O}\right) .{ }^{13} \mathrm{C}-\mathrm{NMR}\left(\mathrm{CDCl}_{3}\right) \delta: 64.5\left(\mathrm{OCH}_{2} \mathrm{CO}\right), 65.6\left(\mathrm{OCH}_{2}\right)$,
117.4-139.0 (aromatic Cs), 143.6 (C-8a quinazoline), 147.2 (C-1 phenoxy), 158.3 ( $\mathrm{C}=\mathrm{O}$ quinazoline), 164.0 (C-2-quinazoline), 167.1 (COO), 169.2 (CONH). IR cm ${ }^{-1}: 3310(\mathrm{NH}) ; 3067$ (CH aromatic), 2949 (CH aliphatic), 1726, 1693 (COs), $771(\mathrm{C}-\mathrm{Cl})$. MS $m / z$ (\%): [M] 498 (3.39), $[\mathrm{M}+2]^{+} 500$ (1.19), 105 (100). Anal. Calcd for $\mathrm{C}_{24} \mathrm{H}_{17} \mathrm{Cl}_{2} \mathrm{~N}_{3} \mathrm{O}_{5}$ (498.31): C, 57.85; H, 3.44; N, 8.43. Found: C, 57.90; H, 3.68; N, 8.52.

[2-(2,4-Dichlorophenoxy)methyl-4-oxo-4H-quinazolin-3ylcarbamoyl]methyl 2-Chloro-benzoate (8c): $\mathrm{mp} 185-187^{\circ} \mathrm{C}$; yield 67\%. ${ }^{1} \mathrm{H}-\mathrm{NMR}\left(\mathrm{CDCl}_{3}\right) \delta: 5.08\left(2 \mathrm{H}, \mathrm{s}, \mathrm{CH}_{2} \mathrm{CO}\right), 5.34$ $\left(2 \mathrm{H}, \mathrm{s}, \mathrm{CH}_{2} \mathrm{O}\right), 7.15-7.97(10 \mathrm{H}, \mathrm{m}$, aromatic $\mathrm{H}), 8.16(1 \mathrm{H}, \mathrm{d}$, $J=6.6 \mathrm{~Hz}, \mathrm{C} 5-\mathrm{H}$ quinazoline), $11.58(1 \mathrm{H}, \mathrm{s}, \mathrm{NH}$ exchangeable with $\left.\mathrm{D}_{2} \mathrm{O}\right)$. IR $\mathrm{cm}^{-1}$ : $3422(\mathrm{NH}), 3212$ ( $\mathrm{CH}$ aromatic), 2934 (CH aliphatic), 1691 (COs), $772(\mathrm{C}-\mathrm{Cl})$. Anal. Calcd for $\mathrm{C}_{24} \mathrm{H}_{16} \mathrm{Cl}_{3} \mathrm{~N}_{3} \mathrm{O}_{5}$ (532.76): C, 54.11; H, 3.03; N, 7.89. Found: C, 54.37; H, 3.26; N, 7.70.

General Procedure for the Synthesis of Compounds $(9 \mathbf{a}-\mathbf{c})$ A mixture of $7(0.41 \mathrm{~g}, 1 \mathrm{mmol})$, the appropriate amine $(1.1 \mathrm{mmol})$ and anhydrous potassium carbonate $(0.21 \mathrm{~g}$, $1.5 \mathrm{mmol})$ in acetonitrile $(30 \mathrm{~mL})$ was refluxed for $8 \mathrm{~h}$. The reaction mixture was filtered while hot and the filtrate was concentrated and cooled. The separated solid was filtered off, dried and recrystallized from aqueous ethanol.

2-(4-Chlorophenylamino)- $N$-[2-(2,4-dichlorophenoxy)methyl-4-oxo-4H-quinazolin-3-yl]acetamide (9a): $\mathrm{mp}$ 190-191 ${ }^{\circ} \mathrm{C}$; yield $60 \%$. ${ }^{1} \mathrm{H}-\mathrm{NMR}\left(\mathrm{CDCl}_{3}\right): \delta 5.14(2 \mathrm{H}, \mathrm{s}$, $\left.\mathrm{CH}_{2} \mathrm{CO}\right), 5.31\left(2 \mathrm{H}, \mathrm{s}, \mathrm{CH}_{2} \mathrm{O}\right), 6.96-7.81(12 \mathrm{H}, \mathrm{m}, 10$ aromatic $\mathrm{CH}$ and $2 \mathrm{NHs}$ exchangeable with $\left.\mathrm{D}_{2} \mathrm{O}\right), 8.30(1 \mathrm{H}, \mathrm{d}, J=7.2 \mathrm{~Hz}$, C5-H quinazoline). IR cm ${ }^{-1}: 3420$ (NHs), 3040 (CH aromatic), 2925 (CH aliphatic), 1686 (COs), 771 (C-Cl). Anal. Calcd for $\mathrm{C}_{23} \mathrm{H}_{17} \mathrm{Cl}_{3} \mathrm{~N}_{4} \mathrm{O}_{3}$ (503.76): C, 54.84; H, 3.40; N, 11.12. Found: $\mathrm{C}$, 55.20; H, 3.57; N, 10.90 .

$\mathrm{N}$-[2-(2,4-Dichlorophenoxy)methyl-4-oxo-4H-quinazolin-3yl]-2-( $N^{\prime}$-phenylhydrazino)acetamide (9b): $\mathrm{mp} \quad 200-202^{\circ} \mathrm{C}$; yield $65 \%$. ${ }^{1} \mathrm{H}-\mathrm{NMR}\left(\mathrm{CDCl}_{3}\right) \delta: 5.12\left(2 \mathrm{H}, \mathrm{s}, \mathrm{CH}_{2} \mathrm{CO}\right), 5.36$ $\left(2 \mathrm{H}, \mathrm{s}, \mathrm{CH}_{2} \mathrm{O}\right), 7.13-7.76(11 \mathrm{H}, \mathrm{m}$, aromatic $\mathrm{CH}), 8.23(1 \mathrm{H}, \mathrm{d}$, $J=7.2 \mathrm{~Hz}, \mathrm{C} 5-\mathrm{H}$ quinazoline), $11.78(3 \mathrm{H}, \mathrm{s}, 3 \mathrm{NHs}$ exchangeable with $\left.\mathrm{D}_{2} \mathrm{O}\right) .{ }^{13} \mathrm{C}-\mathrm{NMR}\left(\mathrm{CDCl}_{3}\right) \delta$ : $54.6\left(\mathrm{NHCH}_{2} \mathrm{CO}\right), 67.6$ $\left(\mathrm{OCH}_{2}\right), 118.7-139.5$ (aromatic $\left.\mathrm{Cs}\right), 142.1$ (C-8a quinazoline), 147.8 (C-1 phenylhydrazinyl), 148.5 (C-1 phenoxy), 159.4 (C= O quinazoline), 164.4 (C-2-quinazoline), 171.3 (CONH). IR $\mathrm{cm}^{-1}$ : 3402 (NHs), 3187 (CH aromatic), 2926 (CH aliphatic), 1689 (COs), 768 (C-Cl). Anal. Calcd for $\mathrm{C}_{23} \mathrm{H}_{19} \mathrm{Cl}_{2} \mathrm{~N}_{5} \mathrm{O}_{3}$ (484.33): C, 57.04; H, 3.95; N, 14.46. Found: C, 56.88; H, 4.22; $\mathrm{N}, 14.12$.

$N$-[2-(2,4-Dichlorophenoxy)methyl-4-oxo-4H-quinazolin-3yl]-2-[( $N^{\prime}$-pyridine-4-carbonyl)hydrazino $]$ acetamide (9c): $\mathrm{mp}$ 205-206 ${ }^{\circ} \mathrm{C}$; yield 58\%. ${ }^{1} \mathrm{H}-\mathrm{NMR}\left(\mathrm{CDCl}_{3}\right) \delta$ : $5.05(2 \mathrm{H}, \mathrm{s}$, $\left.\mathrm{CH}_{2} \mathrm{CO}\right), 5.36\left(2 \mathrm{H}, \mathrm{s}, \mathrm{CH}_{2} \mathrm{O}\right), 7.02-7.98(10 \mathrm{H}, \mathrm{m}$, aromatic $\mathrm{H}), 8.23(1 \mathrm{H}, \mathrm{d}, J=7.5 \mathrm{~Hz}, \mathrm{C} 5-\mathrm{H}$ quinazoline), $9.70(3 \mathrm{H}, \mathrm{s}$, 3NHs exchangeable with $\mathrm{D}_{2} \mathrm{O}$ ). IR cm $\mathrm{cm}^{-1} 3212$ (NHs), 3070 (CH aromatic), 2925 (CH aliphatic), 1723, 1693 (COs), 773 (C-Cl). MS m/z (\%): [M] 513 (0.22), 131 (100). Anal. Calcd for $\mathrm{C}_{23} \mathrm{H}_{18} \mathrm{Cl}_{2} \mathrm{~N}_{6} \mathrm{O}_{4}$ (513.33): C, 53.81; $\mathrm{H}, 3.53 ; \mathrm{N}, 16.37$. Found: C, 53.65; H, 3.75; N, 16.48 .

Synthesis of 6-(2,4-Dichlorophenoxy)methyl-2H-[1,2,4] triazino[2,3-c]quinazolin-3(4H)-one (10) A mixture of 7 $(0.41 \mathrm{~g}, 1 \mathrm{mmol})$ and anhydrous ammonium acetate $(0.31 \mathrm{~g}$; $4 \mathrm{mmol})$ in glacial acetic acid $(20 \mathrm{~mL})$ was refluxed for $6 \mathrm{~h}$. The reaction mixture was poured onto ice-water and the separated solid was filtered off, washed with water and crys- 
tallized from ethanol. mp $210-211^{\circ} \mathrm{C}$; yield $60 \%$. ${ }^{1} \mathrm{H}-\mathrm{NMR}$ $\left(\mathrm{CDCl}_{3}\right) \delta: 5.15\left(2 \mathrm{H}, \mathrm{s}, \mathrm{CH}_{2} \mathrm{O}\right), 5.31\left(2 \mathrm{H}, \mathrm{s}, \mathrm{CH}_{2} \mathrm{CO}\right), 6.97-7.84$ $\left(7 \mathrm{H}, \mathrm{m}, 6\right.$ aromatic $\mathrm{H}$ and $\mathrm{NH}$ exchangeable with $\left.\mathrm{D}_{2} \mathrm{O}\right), 8.31$ $\left(1 \mathrm{H}, \mathrm{d}, J=7.8 \mathrm{~Hz}, \mathrm{C} 5-\mathrm{H}\right.$ quinazoline). ${ }^{13} \mathrm{C}-\mathrm{NMR}\left(\mathrm{CDCl}_{3}\right) \delta$ : $48.2\left(\mathrm{NHCH}_{2} \mathrm{CO}\right.$ triazine), $69.2\left(\mathrm{OCH}_{2}\right), 115.2-136.2$ (aromatic Cs), 142.5 (C-8a quinazoline), 149.4 (C-1 phenoxy), 163.5 (C-4 quinazoline), 164.4 (C-2-quinazoline), 166.2 (CONH). IR cm ${ }^{-1}$ : $3200(\mathrm{NH}), 3095$ (CH aromatic), 2921 (CH aliphatic), 1718 (CO), 771 (C-Cl). MS m/z (\%): [M] 375 (2.4), [M+2] 377 (0.75), 250 (100). Anal. Calcd for $\mathrm{C}_{17} \mathrm{H}_{12} \mathrm{Cl}_{2} \mathrm{~N}_{4} \mathrm{O}_{2}$ (375.21): C, 54.42; H, 3.22; N, 14.93. Found: C, 54.70; H, 3.50; N, 14.46.

Anticonvulsant Activity. Animal Preparation Adult albino mice weighing 20-25g of both sexes were used throughout this study. Animals were housed in groups of 5 and were allowed free access to food pellets (vit mix $1 \%$, mineral mix $4 \%$ corn oil $10 \%$, sucrose $20 \%$, cellulose $0.2 \%$, casein $(95 \%$ pure) $10.5 \%$, starch $54.3 \%$ ). All behavioral experiments were conducted during the period between 10:00 and 13:00 with normal room light ( $12 \mathrm{~h}$ regular light/dark cycle) and temperature $\left(22 \pm 2^{\circ} \mathrm{C}\right)$. The experimental procedures were carried out in strict compliance with the Animal Ethics Committee regulations of the Faculty of Veterinary Medicine, Cairo University. All experiments were carried out in the morning according to the guidelines for the care of laboratory animals. ${ }^{31)}$

The s.c. PTZ-Induced Seizure Test The tested compounds were administered orally to mice in a dose of $100 \mathrm{mg} /$ $\mathrm{kg}$ body weight. This dose was determined depending a doseresponse curve of some tested compounds. Tested compounds were prepared as suspension in $2 \%$ Tween 80 . Phenobarbitone sodium was used as a reference standard in a dose of $30 \mathrm{mg} /$ $\mathrm{kg}$ body weight. Thirty minutes later, mice received $80 \mathrm{mg} /$ kg PTZ via subcutaneous injection. ${ }^{32)}$ A positive control group receiving only PTZ was conducted. An episode of clonic spasms, approximately $3-5 \mathrm{~s}$, of the fore and/or hind limbs, jaws, or vibrissae is taken as the endpoint. Animals which do not meet this criterion are considered protected. The number of protected animals in each group was recorded and percentage protection was calculated (Table 1$)$. $\mathrm{PD}_{50}$ values for the most active compounds and phenobarbitone were also performed and calculated in $\mu \mathrm{mol} / \mathrm{kg}$ (Table 2).

The MES Test The procedure was carried out as described by Krall et al. ${ }^{33)}$ and Kitano et al. ${ }^{34)}$ Electroshock was applied via ear-lip electrodes and generated by a stimulator that delivers an alternating $60 \mathrm{~Hz}$ current by Ugo Basile ECT Unit Pulse generator 57800-001. The stimulus duration was $2.5 \mathrm{~s}$; the end point was tonic hind limb extension. ${ }^{35)}$ The maximum electro-shock was determined. Phenytoin and the tested drugs were administered orally at a dose of $0.2 \mathrm{mmol} / \mathrm{kg}$ body weight, $60 \mathrm{~min}$ before the test. The mean threshold current for electroshock-induced hind limb tonic seizure was calculated for each drug (Table 1).

Acute Toxicity $\left(\mathbf{L D}_{\mathbf{5 0}}\right)$ The acute toxicity $\left(\mathrm{LD}_{50}\right)$ of the most active compounds in mice $(n=12)$ was estimated according to the method of Lorke. ${ }^{36)}$ In stage one of the test, animals received oral doses of $10,100,1000 \mu \mathrm{mol} / \mathrm{kg}(n=3)$ of the tested compounds and observed for $24 \mathrm{~h}$ for number of deaths. Since no deaths occurred in any of the groups in the first stage of the test, 1500,2000 and $3000 \mu \mathrm{mol} / \mathrm{kg}$ doses of the compounds were administered to a fresh batch of animals $(n=1)$ where no deaths were recorded within the next $24 \mathrm{~h}$. Thus, the oral $\mathrm{LD}_{50}$ in mice was found to be greater than
$3000 \mu \mathrm{mol} / \mathrm{kg}$ (Table 3). Therapeutic index $\left(\mathrm{LD}_{50} / \mathrm{PD}_{50}\right)$ was also calculated and included in Table 3.

Neurological Toxicity Study Toxicity induced by a compound is detected in mice using the standardized rotarod test described by Dunham and Miya. ${ }^{37)}$ Untreated control mice, when placed on a $6 \mathrm{rpm}$ rotation rod, can maintain their equilibrium for a prolonged period of time. The animal is considered toxic if it falls off this rotating rod three times during a $1 \mathrm{~min}$ period. In addition to muscular impairement, animals may exhibit a circular or zigzag gait, abnormal body posture and spread of the legs, tremors, hyperactivity, lack of exploratory behavior, somnolence, stupor, catalepsy, loss of placing response and changes in muscle tone. Results are presented in Table 4.

Flexible Alignment Flexible alignment of reference compounds illustrated in Fig. 1 and the target (test) compounds 6d, 8c, 9b and 10 was carried out with the software, Molecular Operating Environment. ${ }^{38)}$ The molecules were built using the Builder module of MOE. Their geometry was optimized by using the MMFF94 force-field; 200 conformers of each compound were generated and minimized with a distancedependant dielectric model. A low energy set of 100 was selected for further analysis. Conformations of the compounds were generated using distance geometry and optimized with MMFF94. After assigning MMFF94 charges to all molecules, flexible alignment was employed to scan and rank overlays of the compounds based on steric, electrostatic field, hydrophobic areas overlap, hydrogen bond donors and acceptors overlap. From the top scoring superpositions, several sets were selected and subjected to more refined searching using MOE/flexible alignment module. Since the molecules are highly flexible, the limited set of conformers used in the analysis was not capable of achieving complete atom-to-atom superposition. The distances between the common pharmacophoric features in the reference and test sets were then measured.

Acknowledgment The authors would like to thank Dr. Yassin M. Nissan, Molecular Modeling Laboratory, Faculty of Pharmacy, Cairo University, for his efforts in performing the molecular modeling study.

\section{References and Notes}

1) Stefan H., Feuerstein T. J., Pharmacol. Ther., 113, 165-183 (2007). 2) Donner E. J., Snead O. C. 3rd, NeuroRx, 3, 170-180 (2006).

3) McNamara J. O., "The Pharmacological Basis of Therapeutics," ed. by Brunton L. L., Lazo J. S., Parker K. L., McGraw-Hill, New York, 2006, pp. 501-526.

4) Kwan P., Brodie M. J., N. Engl. J. Med., 342, 314-319 (2000). 5) Spear B. B., Epilepsia, 42 (Suppl. 5), 31-34 (2001).

6) Löscher W., Schmidt D., Epilepsy Res., 50, 3-16 (2002). 7) Löscher W., Schmidt D., Epilepsy Res., 69, 183-272 (2006). 8) Greenwood R. S., Epilepsia, 41 (Suppl. 2), S42-S52 (2000).

9) Deng X. Q., Wei C. X., Li F. N., Sun Z. G., Quan Z. S., Eur. J. Med. Chem., 45, 3080-3086 (2010).

10) Karakurt A., Ozalp M., Işik S., Stables J. P., Dalkara S., Bioorg. Med. Chem., 18, 2902-2911 (2010).

11) Alam O., Mullick P., Verma S. P., Gilani S. J., Khan S. A., Siddiqui N., Ahsan W., Eur. J. Med. Chem., 45, 2467-2472 (2010).

12) Bruno-Blanch L., Gálvez J., García-Domenech R., Bioorg. Med. Chem. Lett., 13, 2749-2754 (2003).

13) Pandeya S. N., Raja A. S., Stables J. P., J. Pharm. Pharm. Sci., 5, 266-271 (2002). 
14) Estrada E., Peña A., Bioorg. Med. Chem., 8, 2755-2770 (2000).

15) Al-Obaid A. M., Abdel-Hamide S. G., El-Kashef H. A., Abdel-Aziz A. A., El-Azab A. S., Al-Khamees H. A., El-Subbagh H. I., Eur. J. Med. Chem., 44, 2379-2391 (2009).

16) El-Azab A. S., Al-Omar M. A., Abdel-Aziz A. A., Abdel-Aziz N. I., el-Sayed M. A., Aleisa A. M., Sayed-Ahmed M. M., Abdel-Hamide S. G., Eur. J. Med. Chem., 45, 4188-4198 (2010).

17) Alafeefy A. M., Kadi A. A., El-Azab A. S., Abdel-Hamide S. G., Daba M. H., Arch. Pharm. (Weinheim), 341, 377-385 (2008).

18) Al-Omary F. A., Abou-Zeid L. A., Nagi M. N., Habib E.-S. E., Abdel-Aziz A. A.-M., El-Azab A. S., Abdel-Hamide S. G., Al-Omar M. A., Al-Obaid A. M., El-Subbagh H. I., Bioorg. Med. Chem., 18, 2849-2863 (2010).

19) El-Azab A. S., Phosphorus Sulfur Silicon Relat. Elem., 182, 333 348 (2007).

20) Gujral M. L., Sareen K. N., Kohli R. P., Indian J. Med. Res., 45, 207-211 (1957)

21) Wolfe J. F., Rathman T. L., Sleevi M. C., Campbell J. A., Greenwood T. D., J. Med. Chem., 33, 161-166 (1990).

22) Aziza M. A., Az. J. Pharm. Sci, 19, 129-135 (1997).

23) El-Azab A. S., Eltahir K. E. H., Bioorg. Med. Chem. Lett., 22, 327-333 (2012).

24) Orain D., Ofner S., Koller M. I., Carcache D. A., Froestl W., Allgeier H., Rasetti V., Nozulak J., Mattes H., Soldermann N., Floersheim P., Desrayaud S., Kallen J., Lingenhoehl K., Urwyler S., Bioorg. Med. Chem. Lett., 22, 996-999 (2012).

25) Kashaw S. K., Gupta V., Kashaw V., Mishra P., Stables J. P., Jain N.
K., Med. Chem. Res., 19, 250-261 (2010).

26) Kumar P., Shrivastava B., Pandeya S. N., Stables J. P., Eur. J. Med. Chem., 46, 1006-1018 (2011).

27) El-Azab A. S., ElTahir K. E. H., Med. Chem. Res., 21, 3785-3796 (2012).

28) Rajak H., Thakur B. S., Kumar P., Parmar P., Sharma P. C., Veerasamy R., Kharya M. D., Acta Pol. Pharm., 69, 253-261 (2012).

29) Abbas S. E., Saafan A. E. M., Bull. Pharm. Sci. Assiut Univ., 30, 51-62 (2007).

30) Georgy H., Gawad N. A., Abbas S. E., Molecules, 13, 2557-2569 (2008).

31) Zimmerman M., Pain, 16, 109-110 (1983).

32) Swinyard E. A., Clark L. D., Miyahara J. T., Wolf H. H., J. Physiol., 132, 97-102 (1961).

33) Krall R. L., Penry J. K., White B. G., Kupferberg H. J., Swinyard E. A., Epilepsia, 19, 409-428 (1978).

34) Kitano Y., Usui C., Takasuna K., Hirohashi M., Nomura M., J. Pharmacol. Toxicol. Methods, 35, 25-29 (1996).

35) Löscher W., Nau H., Marescaux C., Vergnes M., Eur. J. Pharmacol., 99, 211-218 (1984).

36) Lorke D. A., Arch. Toxicol., 53, 275-289 (1983).

37) Dunham N. W., Miya T. S., J. Am. Pharm. Assoc., 46, 208-209 (1957).

38) Molecular Operating Environment (MOE) version 2008.10 release of Chemical Computing Group's. The program operated under 'Windows XP' operating system installed on an Intel Pentium IV $\mathrm{PC}$ with a $2.8 \mathrm{MHz}$ processor and $512 \mathrm{RAM}$. 